\title{
Systematic Review of Varied Exercise Programs on Body Composition and Physical Fitness for Firefighters
}

\author{
Seung-Hee Baek', Jung-Jun Park², Deong-II Seo ${ }^{3}$, Wook Song ${ }^{4}$, Chung Gun Lee ${ }^{4}$, \\ Han-Joon Lee ${ }^{5}$, Yeon Soon Ahn', Hyun-Joo Kang ${ }^{1 *}$
}

\author{
'Soonchunhyang University, Asan, Korea \\ ${ }^{2}$ Pusan National University, Busan, Korea \\ ${ }^{3}$ Dongguk University, Seoul, Korea \\ ${ }^{4}$ Seoul National University, Seoul, Korea \\ ${ }^{5}$ University of Ulsan, Ulsan, Korea \\ ${ }^{6}$ Yonsei University, Seoul, Korea
}

Received: August 7, 2018

Accepted: September 28, 2018

Published online: October 31, 2018

\section{Keywords:}

Body composition

Exercise program

Firefighter

Physical fitness

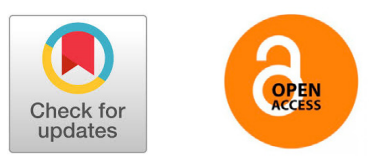

\begin{abstract}
OBJECTIVES Firefighting is one of the most hazardous, physically demanding professions that must possess relatively high levels of physical fitness to perform in a safe and efficient manner. Considering the intense nature of their work, firefighters requires regular exercise training to ensure optimal levels of occupational performance. This study suggests effective guidelines in different exercise programs for preventing injury and improving physical fitness through a systematic review of precedent literature about firefighters. METHODS In this systematic review, the Cochran's PICOTS-SD method (2009), which is based on precedent literature published by many researches was selected. We revised using appropriate key words from precedent literature for our present study. Finally, seven studies were selected from articles based on the time period from 2001 to 2018.2, Institutional Review Board (IRB) approval or randomly assigned.

RESULTS Results showed useful information in the exercise field through analyzing exercise programs. Health-related physical fitness in firefighters showed significant differences before and after exercise participation, such as muscular fitness, cardiorespiratory fitness, and body composition.

CONCLUSIONS The research suggest that an exercise program for firefighters could ensure optimal levels of occupational performance and endurance. It is hoped that the results of these studies will encourage those firefighters who are responsible for the public's safety to participate in required exercise programs.
\end{abstract}

(c) The Asian Society of Kinesiology and the Korean Academy of Kinesiology
서론

소방공무원의 업무는 과거 화재 예방과 진압 위주로 수 행하다가 각종 재난 및 재해의 발생과 국민들의 소방행정 에 대한 수요증가로 인해 구조와 구급 업무가 확대되었다.

*Correspondence: Hyun-Joo Kang, Department of Sports Medicine, Soonchunhyang University, 22 Soonchunhyang-ro, Asan, 31538, Republic of Korea

E-mail:violethjk@hanmail.net
화재진압이나 구급 및 구조는 소방공무원의 목숨을 잃을 수도 있는 위험한 악조건 속에서 국민의 생명과 재산을 보 호하기 위하여 활동해야만 하는 특수한 성격을 지니고 있 다. 산소통이나 호흡마스크와 같은 임무수행에 필요한 중 량의 장비를 착용한 상태로 화재를 진압하기 위해 소방 호 스나 파괴 장비 등 무거운 장비를 다룰 수 있어야 하며, 의 식을 잃고 위험한 상황에 처해 있는 사람을 안전한 곳으로 옮길 수 있어야 한다[1]. 소방공무원은 위험한 현장 활동 에서 매우 격렬한 신체적 활동과 상당히 높은 체력이 요구 
되는 직업군 중에 하나이다[2]. 이러한 특수성으로 국내 소방공무원들은 업무 중 순직, 공·사상, 외상 후 스트레스 등으로 매우 고통받고 있으며, 소방공무원의 순직 및 공. 사상 현황을 보면, 다른 어떤 직종보다 질병 발생 및 사고 의 위험이 높은 것으로 보고되고 있다[3]. 긴급하고 위험 한 화재 진압 시 소방공무원의 근골격계 부상과 체력 부 족은 인명 구조능력을 떨어지게 하므로 각종 위험요인으 로 소방공무원을 보호하기 위해서는 체력증진은 선택이 아닌 필수라 할 수 있다[4].

소방방재청 훈련 128호의 "소방활동 안전관리 규정" 제20조에는 “소방공무원은 자신에게 적합한 체력단련 및 건강관리를 해야 한다"고 명시하고 있으며, 2004년 개정된 동령의 "소방공무원 체력관리 규칙"에 의해 매년 소방공무원 체력검정을 실시하도록 규정되어 있다[5]. 하지만 소방공무원 근무규칙에 제시된 소방공무원 근무 일과표 예시에 따르면, 외근 근무 일과 중에 체력관리 시 간은 1 시간만이 편성되어 있고[3], "소방공무원 체력관 리 규칙"에 따라 소방본부, 소방학교, 소방서는 체력관리 기관으로 소속 소방공무원의 체력관리 프로그램을 운영 하고 있으나, 소방공무원 체력요구 기준에 부합할 수 있 는 과학적이고 체계적인 체력향상 프로그램은 상당히 미 흡한 실정이다. 현행 소방공무원의 체력단련을 위한 각종 프로그램은 소방직무와 현장 활동과의 관련성이 적고 체 력측정 기준도 부적합하므로 소방 현장 활동상 필요한 체 력을 갖추기 위하여 과학적 근거에 의한 교육프로그램의 필요성을 강조하였다[6]. 소방공무원의 체력과 건강상태 가 임무수행 중 근관절 부상과 관련이 있으므로 체력과 건강유지 프로그램의 개발과 도구화에 대한 필요성을 강 조하였는데, 이는 소방공무원을 위한 실질적인 운동프로 그램들이 매우 부족하다는 사실을 반증한다[7].

소방공무원의 직무수행 환경과 활동조건은 물리적으 로 위험환경에 노출되어 있기 때문에 소방업무수행을 위 한 최소한의 체격 및 체력을 제시하고 있다[8]. 국외연구 에 따르면, 소방공무원의 체력수준이 높을수록 구조업무 수행 성공률이 높다고 하였고[9], 다른 연구에서도 소방 대원의 화재 구조 현장에서 임무수행 능력과 체력과의 높 은 상관성을 규명하였다[10]. 선진국에서 소방공무원을 선발하기 위한 실시하는 CPAT(Candidate Physical Ability Test)와 생리적인 요인을 분석한 결과, $\mathrm{CPAT}$ 를 통과한 합 격생은 최대산소섭취량과 최고파워가 매우 높았으며, 상지 근력, 심박수 반응 등도 상관이 있음을 보고하였다
[11]. 즉, 소방현장에서 부상을 최소화하고 효율적으로 안전하게 임무를 수행하기 위해서는 소방 활동에 적합한 체력을 갖추고 있어야만 하며, 이를 위해서는 적절한 운 동프로그램과 규칙적인 실천을 통해서만 가능하다고 하 겠다. 안전하고 성공적인 임무수행은 격하고 위험한 신 체활동을 무리 없이 수행할 수 있는 소방공무원의 체력 적 능력에 따라 좌우되기 때문이다[12]. 최근 들어 소방 공무원의 현장 활동과 관련된 직무는 사회 환경의 변화 와 함께 절대적인 체력이 필요하며, 각종 소방현장에서 부상을 낮추고 안전하게 임무를 수행하기 위해서는 일정 수준 이상의 체력과 이를 위한 지원이 절실하게 필요한 상황이다.

따라서 본 연구의 목적은 소방공무원 업무 중 발생할 수 있는 부상을 최소화하고 현장 활동을 효율적으로 수행 하기 위한 체력증진 운동프로그램 연구를 체계적으로 고 찰하여 프로그램의 효과성을 검증하고자 하였으며, 검증 한 자료를 근거로 하여 소방공무원의 체력관리와 증진에 필요한 자료를 제공하고자 한다.

\section{연구 방법}

국내.외에서 수많은 저자들에 의해 출판된 연구의 체 계적 고찰을 위해 문헌 검토 기준을 정하고 문헌 검색 및 선별 방법에 따라 논문을 선정하였으며, 본 연구의 체계 적 고찰에 대한 연구방법은 다음과 같다.

\section{문헌 검토 기준}

Cochran's PICOTS-SD(Participants, Interventions, Comparisons, Outcomes, Timing, Setting, Study Design) meth$\operatorname{od}(2009)$ 에 따라 문헌 검토 기준을 선정하고 본 연구에 적합하게 수정하여 진행하였다[13]. 수정한 선정기준에 따르면, 연구 대상자 $(\mathrm{P})$ 는 소방공무원, 중재 방법 $(\mathrm{I})$ 은 구 조화된 운동 또는 재활 프로그램, 비교군(C)은 비교집단 이나 전.후 처치 비교, 결과 $(\mathrm{O})$ 는 체력요소나 연구 목적 과 관련된 효과, 시점 $(\mathrm{T})$ 은 연구 진행 전과 후 또는 전, 중, 후, 세팅 $(\mathrm{S})$ 은 소방기관 내에서나 피트니스센터 등 지역 사회 대상, 연구 설계(SD)는 무선할당통제연구나 IRB 승 인을 받은 실험설계로 정하였다. 소방공무원을 대상으로 운동프로그램 효과의 체계 연구를 위하여 밀접하게 연관 되어 있는 단어와 신뢰성과 타당성이 있는 연구를 포함범 위로 하였다. 


\section{문헌 검색 및 선별 방법}

문헌 검색은 Cochran's PICOTS-SD method에 가이드 라인에 따라 수정된 주요어인 소방공무원, 운동프로그 램, 재활프로그램 중심으로 국외 논문 검색 사이트 $(\mathrm{Pu}-$ bMed, Medline, Science Direct, Google Scholar)와 국내 논문 사이트(국회도서관, RISS, KISS, DBPIA)에서 2001년부터 2018년 2월까지 연구된 논문을 중심으로 검색하였다. 연구자의 검토과정을 거쳐 국문과 영문으로 작성되지 않 은 논문 및 이전 발표한 자료를 바탕으로 다시 게재한 논 문은 배제하였다.

\section{결과}

국외논문은 PubMed, Medline, Science Direct, Google Scholar 검색 사이트에서 문헌 검색을 통하여 firefighter 분 류에서 5176개의 논문을 검색하였고 다음으로 제목을 통한 firefighter exercise, firefighter rehabilitation, firefighter fitness 분류에서 1820 개의 논문을 선별하였으며, 그 중 firefighter exercise program, firefighter rehabilitation program 분류를 통해 744 개의 논문을 검색하였다. 다음으로 제목 과 요약본을 통해 관련성을 검토하였으며, 전문 소방공 무원, 무작위 선별하여 실시한 실험연구, IRB승인을 받은 논문 총 6편을 선정하였다. 국내논문은 국회도서관, RISS, KISS, DBPIA 검색사이트를 이용하여 소방공무원을 주요 어로 하는 2348 개의 논문을 검색하였고 그 가운데 소방 공무원의 운동, 체력, 재활과 관련 있는 논문 127 편으로 선별하여 무선할당통제연구 방법으로 수행했거나 IRB에 승인된 실험논문 18 개 중 배제 사항을 제외하고 2 편을 선정하였다. 선정된 국외와 국내 논문 총 8 편 가운데 저 자가 중복되고 연구방법과 내용이 동일하며 이미 발표된 논문을 다시 게재한 연구 한 편을 제외하고 최종적으로 7 편을 선정하였다.

소방공무원의 운동프로그램과 관련된 체계적인 고찰 을 위하여 선정한 7 개의 논문은 가장 빠르 게 출판된 시기 에 따라 영어 알파벳을 순서대로 부여하였으며, (Table 1) 에 요약하였다.

연구A[14]는 신임소방관을 대상으로 감독 하에 운동 프로그램을 진행하여 신체조성 및 체력의 변화를 살펴보 고자 하였다. 16 주간의 운동프로그램은 $\operatorname{ACSM}($ American College of Sports Medicine)과 NSCA(National Strength and Conditioning Association)에서 인증한 운동프로그램을 근
거로 하여 감독 하에 실시하였다. 1 시간 동안 실시하는 운동프로그램은 심혈관계 컨디셔닝, 근체력, 직무와 관 련된 활동, 복부/등 컨디셔닝 중심으로 구성하였다. 체력 평가로 신체조성은 7부위 피부두겹법으로 측정하고, 유 연성은 앉아 윗몸앞으로굽히기 검사로 실시하였다. 상 지 근력은 악력계로 측정하였으며, 상지 근지구력은 팔 굽혀펴기를 통해 평가하였다. 최대산소섭취량은 연령 으로 예측된 심박수의 $85 \%$ 에 도달했을 때 종료하는 최 대하 자전거에르고미터 검사 프로토콜을 통하여 산출하 였다. 연구 결과, 16 주간 훈련 후 신입소방공무원의 제 지방 $(\mathrm{p} \leq 0.007), \quad$ 최대산소섭취량 $((\mathrm{p} \leq 0.007), \quad$ 근지구력 $((\mathrm{p} \leq 0.007)$ 과 유연성 $(\mathrm{p} \leq 0.007)$ 모두 유의하게 향상되었 고, 체지방 $(\mathrm{p} \leq 0.007)$ 은 유의한 감소를 보여 직무에 필요 한 체력요소들이 향상됨을 나타냈다.

연구B[15]는 소방공무원은 정상인과 비교하여 대사 증후군 유병률이 4 배 이상 높게 나타난 선행연구를 근거 로 대사증후군 위험요인을 낮추기 위한 목적에 따라 12 주간의 저혈당영양-체력프로그램을 진행하였다. 프로그 램에 참여한 소방공무원 가운 데 대사증후군은 $46.7 \%$ 로 선행연구에서 제시한 결과와 유사하게 정상집단보다 높 은 유병율을 보였다. 운동프로그램은 자격을 갖춘 운동 지도자의 감독 하에 주에 2 시간 동안 실시하였으며, 유 연성 향상을 위한 스트레칭/요가운동, 저항/근력강화운 동, 최대심박수의 50-60\%에 해당하는 심폐지구력 컨디 셔닝, 최대심박수의 $60-70 \%$ 에 해당하는 지방연소운동, 최대심박수의 $70-80 \%$ 에 해당하는 심폐지구력 강화운동 으로 구성하였다. 일상생활에서는 만보계를 착용하고 일 일 60-90분동안 저-중강도로 만보걷기를 권장하였으며, 매일 일지를 기록하고 주 1 회 체중변화를 확인하였다. 운 동프로그램과 동시에 Mediterranean and DASH 식단 가이 드라인에 맞는 식단프로그램도 제공하였다. 인체계측과 대사증후군 위험요소는 프로그램 시작한 후 6 주와 12 주 에 측정하였고, 프로그램 종료 후 6 개월 후에 재측정하 였다. 저혈당영양-체력프로그램 시작 후에 체중, 체지방, 체질량지수, 인체둘레, 대사증후군의 위험요인과 유병율 이 유의하게 감소하였다(p「0.05). 프로그램이 종료되고 6 개월에 다시 상승하는 경향을 나타냈으나 프로그램 시 작 전보다는 허리둘레를 제외하고 전반적으로 어느 정도 향상된 수치를 유지하였으며, 연구에서 제시한 프로그램 은 심혈관질환의 위험요인이 될 수 있는 대사증후군 유병 률 감소에 가장 긍정적인 결과를 가져왔다. 
Table 1. Summary of Literature Review

\begin{tabular}{cccccc}
\hline $\begin{array}{c}\text { Reference } \\
\text { (year) }\end{array}$ & $\begin{array}{c}\text { Group } \\
\text { (N) }\end{array}$ & $\begin{array}{c}\text { Age } \\
\text { (year) }\end{array}$ & Research object & Exercise protocols & Analysis methods \\
\hline
\end{tabular}

$\begin{array}{ccc}\begin{array}{c}\text { Roberts et al. } \\ (2002)\end{array} & \begin{array}{c}\text { Exercise } \\ \text { (115) }\end{array} \quad 28.3 \pm 4.3 & \begin{array}{l}\text { Evaluate fitness } \\ \text { levels of rookie } \\ \text { firefighters }\end{array}\end{array}$

$\begin{array}{ccc}\text { Carey et al. } & \text { Exercise }(75) \quad 42 \pm 7.5 \\ \text { (2011) } & \end{array}$

$\begin{array}{cccl}\text { Gwon HJ } & \text { Exercise (8) } & 45.1 \pm 2.2 & \begin{array}{l}\text { Effect lumbago } \\ \text { rehabilitation } \\ \text { program on } \\ \text { firefighters with } \\ \text { LBP }^{\mathrm{d}}\end{array} \\ \text { (2013) } & \text { Control (8) } & 41.6 \pm 4.2\end{array}$

Mayer et al. $\begin{array}{lr}\text { Exercise (54) } & 37.6 \pm 9.8 \\ \text { Control (42) } & 31.3 \pm 8.0\end{array}$
Effect low glycemic

nutritional fitness program while on duty to reverse MetS

Effect lumbago
rehabilitation
program on
firefighters with
LBP

Effect supervised worksite exercise while on duty on muscle back and core

$1 \mathrm{~h} \cdot \mathrm{d}^{-1}, 3 \mathrm{~d} \cdot \mathrm{wk}^{-1}$ for 16 weeks

Supervised exercise program

Cardiovascular conditioning (20-30min)

Muscle strength/endurance (20-30)

Job-specific activities (2030)

2-Hr weekly sessions $12-$ week

$\checkmark \cdot \mathrm{O}_{2} \max$ (submaximal cycle ergometry)

body composition (skinfold test)

flexibility (sit and reach test)

strength (hand grip) muscle endurance (push-up)

$\uparrow \mathrm{V} \cdot 02 \max (p \leq 0.007)$

$\uparrow$ Muscle strength $(p=0.06)$

$\uparrow$ Flexibility $(p \leq 0.007)$

$\uparrow$ Lean tissue mass $(p \leq 0.007)$

$\downarrow$ Fat mass $(p \leq 0.007)$

\section{$\downarrow 3.2 \pm 1.6$ vs $1.9 \pm 1.7$ MetS} risk factors

$(p<0.01)$ at pre and post

Resistance/strength training, MetSa: waist $\geq 40(\mathrm{M})$ or

Cardiovascular training with $\quad \geq 35 \mathrm{mmHg}$ (W), BP $\geq 135$ or 50\%-80\% THR

Daily activity (60 to $90 \mathrm{~min}$ ) with

(M) or $<50 \mathrm{mg} / \mathrm{dl}$ (W)

$\downarrow$ WCc (2.4inches)

$\downarrow \mathrm{SBP}(10.8 \mathrm{mmHg})$

$\downarrow \mathrm{DBP}(5.8 \mathrm{mmHg})$

acquiring 10,000 steps

$\downarrow$ FBS $(21.8 \mathrm{mg} / \mathrm{dl})$

$25 \min , 2 \cdot d^{-1}, 4 d \cdot w^{-1}$ for 8 weeks

Core isometric exercise (flexion and extension reinforcement)

1-4-wk (10sec $\times 3$ rep/ exercise)

5-6-wk (12sec x xrep / exercise)

7-8-wk (15sec $\times 3 \mathrm{rep} /$ exercise)

$10 \mathrm{~min}^{2} 2 \mathrm{~d} \cdot \mathrm{wk}^{-1}$ for 24 weeks

4 Core isometric exercise (6$8 \mathrm{sec} \times 5 \mathrm{rep} / \mathrm{set}$

1 Progressive resistance exercise for back extension ( 6 angle setting) plus usual fitness program

Control group participants only usual fitness regimen
Abodominal muscular strenght (sit-up holding)

Back muscle strength (sitarch back holding)

Flexibility (sit and reach test)

Balance (single leg with eye closed)

Pain scale (visual analogue scale)

\author{
$\uparrow$ Abdominal muscle strength \\ $(p=0.013)$ \\ $\uparrow$ Back muscle strength \\ $(p=0.000)$ \\ $\uparrow$ Flexibility $(p=0.002)$ \\ $\uparrow$ Balance $(p=0.000)$ \\ $\downarrow$ Pain scale $(\mathrm{p}=0.012)$
}

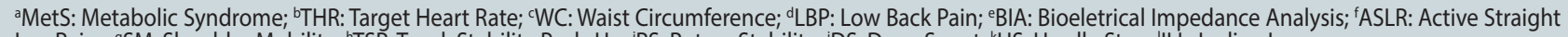

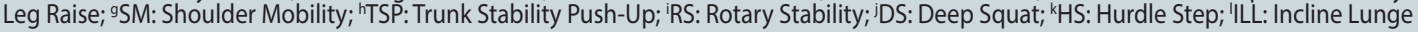

Back muscular endurance (modified Biering-Sorensen Test)

Core muscular endurance (plank Test) $\uparrow$ Back muscular endurance $(p=0.21)$

$\uparrow$ Core muscular endurance $(p=0.006)$ 
Table 1. Summary of Literature Review (cont.)

\begin{tabular}{|c|c|c|c|c|c|c|}
\hline $\begin{array}{l}\text { Reference } \\
\text { (year) }\end{array}$ & $\begin{array}{l}\text { Group } \\
\text { (N) }\end{array}$ & $\begin{array}{c}\text { Age } \\
\text { (year) }\end{array}$ & Research object & Exercise protocols & Analysis methods & Outcome \\
\hline \multirow{3}{*}{$\begin{array}{l}\text { May and } \\
\text { Nuzzo } \\
(2015)\end{array}$} & \multirow{3}{*}{$\begin{array}{l}\text { Supervised } \\
\text { exercise (36), } \\
\text { control (28) }\end{array}$} & \multirow{3}{*}{$\begin{array}{c}36.1 \pm 10.0 \\
31.8 \pm 8.5\end{array}$} & \multirow{3}{*}{$\begin{array}{l}\text { Effect worksite } \\
\text { exercise while on } \\
\text { duty on lumbar } \\
\text { multifidus muscle }\end{array}$} & $\begin{array}{c}\text { 10-15min, } 2 \mathrm{~d} \cdot \mathrm{wk}^{-1} \text { for } \\
\text { 24weeks }\end{array}$ & \multirow{3}{*}{$\begin{array}{l}\text { Lumbar multifidus } \\
\text { muscle cross-sectional } \\
\text { area and asymmetry } \\
\text { (ultrasonography) }\end{array}$} & \multirow{3}{*}{$\begin{array}{l}\text { No significant differences } \\
\text { between the groups by } \\
\text { baseline and scores } L 4 \text { and } L 5 \\
\text { lumbar multifidus muscle and } \\
\text { asymmetry values }\end{array}$} \\
\hline & & & & $\begin{array}{c}4 \text { Core isometric exercise (6- } \\
8 \text { sec } \times 5 \text { rep } / \text { set) } \\
1 \text { Progressive resistance } \\
\text { exercise for back extension } \\
\left(75^{\circ}, 60^{\circ}, 45^{\circ}, 30^{\circ}, 15^{\circ} \text { or }\right. \\
0^{\circ} / \text { set) plus usual fitness } \\
\text { program }\end{array}$ & & \\
\hline & & & & $\begin{array}{l}\text { Control group participants } \\
\text { only usual fitness regimen }\end{array}$ & & \\
\hline \multirow{6}{*}{$\begin{array}{l}\text { Pawlak et al. } \\
\qquad \text { (2015) }\end{array}$} & \multirow{6}{*}{$\begin{array}{l}\text { Supervised } \\
\text { exercise } \\
(11) \\
\text { Control (9) }\end{array}$} & \multirow{6}{*}{$\begin{array}{l}35.0 \pm 6.6 \\
42.3 \pm 5.6\end{array}$} & \multirow{6}{*}{$\begin{array}{c}\text { Effect tactical on- } \\
\text { duty program on } \\
\text { fitness and } \\
\text { occupational } \\
\text { performance }\end{array}$} & \multirow{6}{*}{$\begin{array}{l}\text { 1hr, } 2-3 \mathrm{~d} \cdot \mathrm{wk}^{-1} \text {, for } 12 \text { weeks } \\
\text { Dynamic and static } \\
\text { stretching, circuit training } \\
\text { strength and endurance, } \\
\text { cardiovascular exercise } \\
\text { 10-15rep/exercise(work:rest } \\
\text { ratio 1:1) }\end{array}$} & \multirow{3}{*}{ 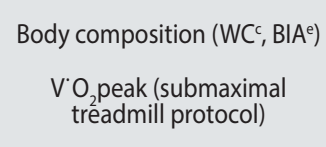 } & \multirow{2}{*}{$\begin{array}{c}\downarrow \text { Fat mass (-10.5\%) } \\
\uparrow \underset{(5.5 \%)}{\text { Cardiovascular fitness }}\end{array}$} \\
\hline & & & & & & \\
\hline & & & & & & \multirow{4}{*}{$\begin{array}{c}\uparrow \text { Muscular strength (7.5\%) } \\
\uparrow \text { Flexibility (9.3\%)f } \\
\downarrow \text { Time to completion on } 4 \\
\text { of } 6 \text { tasks } \\
(-7.5 \%)\end{array}$} \\
\hline & & & & & $\begin{array}{l}\text { Muscular strength (hand } \\
\text { grip) }\end{array}$ & \\
\hline & & & & & Fexibility (sit and reach test) & \\
\hline & & & & & $\begin{array}{l}\text { Task-specific performance (6 } \\
\text { simulated fire ground test) }\end{array}$ & \\
\hline \multirow{5}{*}{$\begin{array}{l}\text { Stanek et al. } \\
\text { (2017) }\end{array}$} & \multirow{5}{*}{$\begin{array}{l}\text { Corrective } \\
\text { exercise (65) }\end{array}$} & \multirow{5}{*}{$40.4 \pm 8.4$} & \multirow{5}{*}{$\begin{array}{l}\text { Effect corrective } \\
\text { exercise on } \\
\text { functional } \\
\text { movement screen } \\
\text { (FMS) scores }\end{array}$} & $\begin{array}{c}\geq 3 \mathrm{~d} \cdot \mathrm{w}^{-1} \text {, self-monitored for } \\
8 \text { weeks }\end{array}$ & \multirow{5}{*}{\multicolumn{2}{|c|}{$\begin{array}{c}\uparrow \text { FMS score (pre: } \\
12.09 \pm 2.75, \\
\text { post: } 13.66 \pm 2.28 \text { ) } \\
\uparrow \text { Stability (pre: } 4.13 \pm 1.21, \\
\text { post: } 4.55 \pm 0.83 \text { ) } \\
\uparrow \text { Advanced movements (pre } \\
4.45 \pm 1.28, \text { post: } \\
5.36 \pm 1.29 \text { ) }\end{array}$}} \\
\hline & & & & $\begin{array}{l}\text { 4-week progressive } \\
\text { correcitve exercise plus }\end{array}$ & & \\
\hline & & & & & & \\
\hline & & & & $\begin{array}{l}\text { FMS (Squating, stepping, } \\
\text { bending, pushing, , and } \\
\text { shoulder \& spinal ratation) }\end{array}$ & & \\
\hline & & & & and prescribed program & & \\
\hline
\end{tabular}

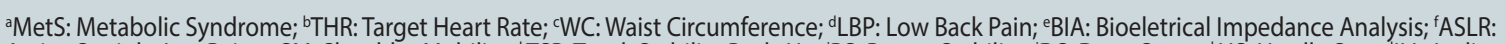
Active Straight Leg Raise; ${ }^{9}$ SM: Shoulder Mobility; ${ }^{~} T S P$ : Trunk Stability Push-Up; ;RS: Rotary Stability; 'DS: Deep Squat; ${ }^{~ H S: ~ H u r d l e ~ S t e p ; ~ I I L L: ~ I n c l i n e ~ L u n g e ~}$

연구C[16]는 허리통증이 있는 40대 소방공무원을 대 상으로 재활프로그램을 진행하였다. 무작위로 할당된 실 험군 8 명과 통제군 8 명에 대하여 프로그램 전후에 체격, 근력, 유연성, 평형성, 주관적 통증정도를 측정하였다. 허 리통증 재활프로그램은 8 주간 주 4 일동안 하루 2 회 허 리 굽힘근 강화운동과 폄근 강화운동을 중심으로 총 25 분간 실시하였다. 1 주차에서 4 주차까지 동작 당 10 초간 3 회, 5주에서 6주차까지는 동작 당 12 초간 3회, 7주차부 터 8 주차까지는 동작당 지속시간 15 초간 3 회로 시간을 증가시키면서 부하량을 늘려 나갔다. 재활프로그램 후 실 험군은 복부근력과 등근력 모두 유의한 향상을 보였으며 $(\mathrm{p}=0.013, \mathrm{p}=0.00)$, 유연성 검사에서도 실험군은 운동 후 유의한 향상 $(\mathrm{p}=0.00)$ 을 보였다. 평형성 변화에서도 실험 군이 유의한 향상을 보였으며 $(\mathrm{p}=0.00)$, 주관적 통증정도 에서도 실험군은 운동 후 통증정도가 감소하였으며, 집 단 간에서도 유의한 차이가 나타났다 $(\mathrm{p}=0.012)$. 소방공 무원에서 빈번하게 발생하는 허리통증을 완화시키고자 실시한 재활프로그램을 통해 허리 근력과 주관적 통증이 긍정적으로 감소하는 결과를 보여 프로그램의 효과를 입 증하였다.

연구D[17]도 소방공무원의 허리통증을 예방하기 위 해 실험군 54 명과 통제군 42 명을 무선할당으로 분류하 
고 코어근육과 등근육의 근지구력을 향상시키는 운동프 로그램을 실시하였다. 운동전문가의 감독 하에 24 주간 주 2 회 근무지 내에서 동일하게 실시하였다. 무작위로 할 당된 실험군에서는 4 가지의 코어운동(Cat camel, Birddog, Curl-up, Side bridge)과 각도 별 등폄 운동 $\left(75^{\circ}, 60^{\circ}, 45^{\circ}\right.$, $30^{\circ}, 15^{\circ}, 0^{\circ}$ )으로 구성하였다. 코어운동은 한 동작 당 6-8 초를 유지하는 것을 5 번씩 반복하고 등폄 운동은 6 개의 각도별로 편심성 수축, 동심성 수축, 등속성 운동을 각 4 초씩 지속하여 12 초간 근지구력을 강화시키도록 구성하 였다. 실험군과 통제군 모두 일상적인 신체활동은 허용 하였다. 운동프로그램 후 modified Biering-Sorensen 검사 를 통해 등폄근육이 $12 \%$ 강화됨을 확인하였고 $(\mathrm{p}=0.21)$, plank 검사로 코어 근지구력도 운동 후에 $21 \%$ 나 유의하 게 향상되는 결과를 확인하였다 $(\mathrm{p}=0.006)$. 허리통증 환 자는 아니지만 코어와 등 근육의 강화로 소방공무원에서 빈발하는 허리통증 예방을 위한 운동프로그램의 유효성 이 검증되었다.

연구 $\mathrm{E}[18]$ 는 연구 $\mathrm{D}[17]$ 의 동일한 연구자가 허리 뭇갈 래근의 비대와 근단면적의 비대칭을 살펴보기 위하여 실 시하였다. 프로그램을 위하여 운동군 36 명, 비교군 28 명 으로 무선할당하여, 24주간 일주일에 2번 10-15분 정도 소방기관에서 실시하였다. 운동프로그램은 연구 $\mathrm{D}$ 와 동 일하게 코어근육과 등근육의 근지구력을 향상시키는 위 한 목적으로 실시하였다. 운동프로그램이 끝난 후 초음 파를 통해 비교한 결과에서 허리 뭇갈래근의 비대와 허 리 좌.우측의 비대칭 정도는 유의하게 변화되지 않았다. 연구결과, 연구자가 구성한 운동프로그램이 허리 뭇갈래 근과 근육 단면적의 비 대칭 정도가 향상되는 효과성은 검 증되지 않았다.

연구F[19]은 소방공무원을 운동군 11 명과 대조군 9 명을 무선할당으로 나누고 직무 수행에 맞도록 새롭게 고안한 서킷트레이닝의 효과를 알아보기 위하여 12 주간 의 감독 하에 진행하였다. 체력은 최대산소섭취량 측정 을 통한 심폐능력, 악력계를 이용한 상지근력, 앉아윗몸 앞으로굽히기 검사를 통한 유연성을 평가하였다. 모의 화 재진압 검사로는 6 가지의 소방현장업무와 관련이 있는 활동(계단오르기, 호스끌기, 강제진입, 사다리연장하기, 장비운반하기, 희생자구조하기)을 최대한 빨리 수행하는 것으로 측정하였다. 서킷프로그램은 스트레칭 동작을 포 함한 정적스트레칭과 동적스트레칭, 근력과 근지구력의 서킷트레이닝, 심폐지구력운동으로 구성하였으며, 일주
일에 2-3회 1시간동안 진행하였다. 운동 동작과 휴식은 1:1 비율로 하여 동작 당 10-15회를 반복할 수 있도록 실 시하였다. 12 주 후 운동집단에서 체지방량(-10.5\%), 심 폐체력(5.5\%), 근력(7.5\%), 유연성(9.3\%)이 상당히 향상 되었고 모의 화재진압 6 가지 활동 중에 4 가지는 시간이 단축되는 결과(-7.5\%)를 가져왔다. 소방공무원에 적합하 게 개발한 서킷트레이닝이 체력과 현장활동과 관련된 업 무활동에서도 효과적임을 입증한 연구이다.

연구G[20]은 소방공무원의 부상 예방을 위하여 8주 간 주 3회 개별화된 교정운동프로그램을 실시하고 Functional Movement Screen(FMS) 점수 변화로 기능체력에 대 한 향상을 증명하고자 하였다. FMS는 7 가지 기능적 동작 패턴으로 효과성을 검증하기 위한 평가 도구이며, FMS 운동 패턴은 소방공무원의 직무 기술과 관련이 있는 쪼 그려 앉기, 걷기, 굽히기, 밀기, 어깨와 척추 회전운동으로 구성하였다. 각 평가는 7가지 FMS 기능적 움직임에 대한 종합 점수로 계산하며, 개별적 FMS검사는 가동성, 안정 성, 숙련된 움직임으로 3 개 범주로 분류하였다. 가동성에 대한 평가는 active straight leg raise(ASLR)와 shoulder mobility(SM), 안정성에 대한 평가는 trunk stability push-up(TSP)과 rotary stability(RS), 숙련된 움직임 평가에는 deep squat(DS), hurdle step(HS), inline lunge(IL)를 실시하였다. 8 주 후 56 명의 소방공무원의 결과를 살펴보면 FMS의 점 수는 유의하게 향상되었고 $(\mathrm{p}<0.001)$, 안정성과 숙련된 움직임 검사에서도 운동 전보다 향상되어 각각 유의한 차 이가 나타났다 $(\mathrm{p}<0.05, \quad(\mathrm{p}<0.001)$. 연구를 통해 소방공 무원에 게 필요한 기능체력의 향상을 위해서 실시한 교정 운동프로그램의 필요성을 강조하였다.

\section{논의}

본 연구에서 분석한 논문들은 Cochran's PICOTS-SD의 지침에 따라 문헌 검토 기준을 정하여 선정한 연구들로 오류와 편향됨을 최소화하려고 노력하였다. 질적 수준이 나신뢰할 만한 결과를 바탕으로 소방공무원을 위한 운동 프로그램의 효과성을 검증할 수 있었으며, 연구E를 제외 하고 연구 목적에 따라 모두 긍정적으로 변화되는 결과를 확인할 수 있었다.

연구A[14]은 신입소방공무원을 대상으로 감독 하에 실시한 운동프로그램이 신체조성과 체력 전반적인 부 분에 향상을 가져왔다. 소방업무를 수행하기 위해서는 
심폐지구력의 가장 중요한 지표인 최대산소섭취량이 $45 \mathrm{mg} \cdot \mathrm{kg}-1 \mathrm{~min}-1$ 정도는 되어야 하는데[21], 운동프로그 램 시작 전 신임소방공무원들은 화재 진압 임무를 수행 하는 데 충분한 심폐능력을 갖추지 못했으나 16 주 훈련 프로그램을 통해 최대산소섭취량이 $45 \pm 6 \mathrm{mg} \cdot \mathrm{kg}-1 \mathrm{~min}-1$ 증가하여 $28 \%$ 까지 향상되는 결과를 보였다. 뿐만 아니 라 근체력, 유연성 모두 향상되었고 체지방 감소와 제지 방이 증가하여 소방공무원의 직무를 효율적으로 수행할 수 있도록 긍정적인 결과를 보였다. 프로그램 진행 후 화 재진압 등 위급한 상황에서 보다 안전하게 현장활동을 수 행할 수 있는 심폐능력에 도달했다는 것에 가장 큰 시사 점이 있는 연구라 할 수 있다. 진행된 프로그램이 20대 후 반의 신임공무원을 대상으로 하여 강도설정을 다소 높게 한 것으로 여겨지나 향후 운동프로그램을 구성할 때는 연 령, 체력수준, 다른 업무 활동 등을 고려하여 개별화된 프 로그램으로 보완된다면 특히, 체력이 저하된 소방공무원 들의 화재진압이나 응급구조 시 부상이 많이 줄어들 것으 로 여겨진다. 통제집단 없이 운동 전후를 비교한 부분에 대해서는 논문의 제한점이나 소방공무원을 대상으로 운 동프로그램을 시도한 거의 최초의 논문이라는 것에 의의 를 둘 수 있을 것이다.

연구B[15]는 소방기관에서 근무시간에 실시한 논문 이며, 이후 연구D,E,F[17,18,19]도 모두 소방기관에서 실 시하여 운동프로그램의 효과를 살펴본 논문들이다. 소방 공무원의 직무 특성상 교대근무나 응급상황 발생 등 개인 적으로 운동프로그램 실천하는데 어려움이 있기 때문에 같은 기관에서 실시함으로써 동일하게 지도하고 동기부 여와 실천율을 높이고자 한 것으로 보인다. 대사증후군 이 있을 경우 심혈관계 질환 발생 위험성이 2 배 정도 높기 때문에 대사증후군 발생과 합병증 예방을 위한 체계적인 관리가 필요하다는 연구[22]와 소방공무원이 다른 직업 군에 비해 직무상 스트레스와 심장 부담 등으로 대사증후 군 유병율이 높게 나온다는 결과를 근거로 하여 체력 증 진보다는 대사증후군 유병률 감소를 위해 시도된 연구라 할 수 있다. NCEP-ATP III 보고(2002)에서는 대사증후군 의 위험인자에 스트레스나 영양불균형과 함께 운동부족 도 원인이라고 하였으며[23], 식이조절과 더불어 규칙적 인 운동은 근력증가와 혈중 지질 개선으로 대사증후군 합 병증 위험을 감소시키는 것으로 운동을 통한 체력관리의 중요성을 강조하였다[24]. 운동의 효과에 대한 선행연구 와 유사하게 연구B에서도 프로그램 진행 후 6주에 가장
효과적인 변화를 가져왔으며, 12 주 프로그램 종료 후 6 개월 후에도 허리-엉덩이둘레와 체지방, 혈압, 중성지방 은 향상된 수치를 유지하였다. 프로그램 종료 후에 다시 상승하는 경향이 나타나긴 했지만 대부분의 위험요소가 여전히 기준치보다 낮은 결과를 보여 저혈당영양-체력프 로그램은 대사증후군의 유병률이 높은 소방공무원에서 도 낮아질 수 있을 것으로 보인다. 아쉬운 부분은 대사증 후군 유병률에 주로 초점을 두어 체력에 대한 평가를 하 지 않았으나 체력의 효과성도 검증했다면 더욱 의미있는 연구가 되었을 것으로 여겨진다. 동일한 근무기관에서 동 일한 스케줄로 식이조절까지 병행했으므로 신체조성과 함께 체력적인 부분도 분명히 향상을 보였을 것으로 판단 된다. 질병에 대한 주의도 필요하지만 직무상 체력이 절 대적으로 요구되는 직업인 만큼 체력 관리와 평가가 지속 적으로 이루어져야 할 것이다. 운동 형태, 강도 등 운동프 로그램에 대한 상세한 설명이 없었지만 향후 체력부분에 좀더 초점을 맞추어 구조화된 운동프로그램을 구성하고 정기적으로 평가 관리한다면 신체적인 능력을 갖추게 되 고 부상이나 질병의 위험도 감소시킬 뿐만 아니라 만성질 환의 위험에서도 긍정적인 영향을 미칠 수 있는 과학적인 프로그램이라 생각된다.

화재진압이나 응급구조 등 강제로 진입하거나 인명을 구조하는 실제 현장에서는 사람을 들거나 무거운 물건을 이동시켜야 하는 경우가 종종 발생하며, 구조과정에서 잘 못된 자세로 여러 신체부위에 부상이 발생하게 된다[25]. 소방직무에 부상 빈도가 높은 부위는 허리로 조사되었으 며[27,27], 연구C,D,E[16,17,18]는 이러한 선행연구 결 과를 바탕으로 하여 허리통증이나 허리통증을 예방하기 위한 운동프로그램을 실시하였다.

연구C[16]은 허리통증이 있는 소방공무원을 대상으 로 재활프로그램을 실시한 연구로 허리 근력에 초점을 맞 추어 허리 근력강화 운동으로 구성하여 진행하였다. 허 리통증과 관련이 있는 굽힘근과 폄근 강화 운동을 실시하 였으며 허리 근지구력과 주관적 통증지표에 향상을 보였 다. 8 주간 주 2 회 25 분이라는 짧은 기간의 중재에 비하면 상당히 의미있는 결과라고 할 수 있다. 소방공무원의 직 무상 허리 통증과 근골격계 부상이 발생하기 이전에 예 방 차원에서 구성하고 근력과 더불어 심폐지구력이나 유 연성 등이 추가적으로 보완된다면 소방공무원이 부상으 로 인한 직무변경, 조기 은퇴나 불필요한 의료비 지출 등 에 매우 긍정적인 영향을 미칠 수 있을 것으로 여겨진다. 
연구D[17]는 소방공무원들의 허리통증을 예방하기 위한 목적으로 24 주 후 집단을 나누어 소방기관에서 등 과 코어근육의 근지구력 강화 운동을 진행하였다. 프로그 램 진행 후, 엎드린 상태에서 등근육으로 지탱하는 modified Biering-Sorensen 검사에서 등근육이 $12 \%$ 향상되는 결과를 보였으며, plank 동작을 통한 검사를 통해 코어 근 력도 $21 \%$ 향상되는 결과를 보였다. 24 주 프로그램으로 기간이 다소 긴 경향은 있으나 프로그램은 일주일에 2번, 10 분의 짧은 시간 동안 실시한 것으로 근무지 내에서 단 체로 실시하기에는 매우 효율적이며 더 큰 동기부여가 되 었을 것으로 판단된다. 연구 $\mathrm{D}$ 는 소방기관에서 실시하였 지만 운동프로그램이나 평가방법도 간단하여 개별적으 로 진행해도 진행상 큰 어려움이 없을 것으로 보여진다. 소방공무원의 특수한 직무상 빈발하는 허리통증을 예방 할 수 있는 근력 강화 운동으로 안전하고 효과적인 프로 그램임을 확인하는 연구라 할 수 있겠다. 추후 소방공무 원을 대상으로 운동프로그램을 구성할 때 근무지 내에서 할 수 있는 프로그램으로 개발한다면 시간을 효율적으로 활용하고 참여자들이 동시에 실시할 수 있으므로 동기부 여와 그룹 내 참여율도 높여 더욱 긍정적인 결과를 예측 할 수 있을 것으로 보인다.

연구 $\mathrm{E}[18]$ 는 연구 $\mathrm{D}[19]$ 에서 소방공무원의 코어 안정 성과 등 근육에 긍정적인 영향을 가져온 결과를 바탕으로 동일한 연구자가 동일한 방법으로 프로그램을 실시하여 허리 근육의 단면적에 대한 변화를 검증하고자 하였다. 일반인을 대상으로 한 연구에서 허리 통증은 허리의 뭇갈 래근과 연관성이 높다는 보고들 $[28,29]$ 을 근거로 운동프 로그램을 통해 소방공무원의 허리 뭇갈래근의 크기와 비 대칭적인 면을 확인하고자 하였다. 프로그램 실시 후 허 리 뭇갈래근의 비대와 허리 좌.우측의 비대칭 정도는 유 의한 차이가 나타나지는 않았다. 기본적으로 일 반인에 비 해 소방공무원은 근육량이 많으며, 허리통증 환자가 아니 라 정상인을 대상으로 한 운동프로그램으로 근비 대나 대 칭 문제에 변화를 가져오기엔 한계가 있었던 것으로도 보 인다. 또한 허리 뭇갈래근은 허리근육 가운데 가장 심부 에 있는 근육으로 일반화된 운동프로그램으로 비대해지 기가 어려울 수 있으며 허리 주위의 다른 근육들을 함께 살펴보는 것도 의미가 있을 것으로 여겨진다. 연구 대상 자를 허리통증이 있는 소방공무원으로 실시하거나 프로 그램 구성요소들을 다르게 적용해간다면 긍정적인 변화 도 기대할 수도 있었을 것으로 생각된다. 연구E에서 실시
한 운동프로그램이 허리 뭇갈래근의 단면적과 비대칭에 변화는 나타나지 않았지만 코어에 중심이 되는 근육으로 소방활동에 있어서도 중요한 역할을 할 것으로 여겨지며, 뭇갈래근을 포함한 코어 근육을 강화하기 위한 프로그램 구성은 반드시 포함되어야 할 것으로 판단된다.

연구F[19]는 기존 서킷 트레이닝에 대한 효과적인 결 과[30,31]를 바탕으로 소방공무원에게도 적용하고자 하 였다. 새롭게 개발한 서킷트레이닝을 12 주간 실시하고 화재진압이나 구조 환경에서 작업 수행력을 검증하고자 한 연구로 현장업무에 대한 실질적인 효과성을 확인하기 위한 중요한 시도라 할 수 있다. 소방기관에서 진행한 서 킷트레이닝 후 모의 화재진압검사에서 $100 \%$ 의 향상을 가져왔으며, 이는 실제 업무를 수행할 때 체력적인 피로 감이나 부상 등에 매우 긍정적이라 할 수 있다. 또한 연 구B,D,E[15,17,18]와 동일하게 근무지에서 실시한 프로 그램으로 본 연구의 서킷트레이닝에 가장 큰 장점은 실 제 현장에서 사용하는 장비인 사다리, 소방호스, 소방도 구 등을 활용할 수 있었다는 것이다. 실제 현장에서 사다 리를 세우고 연장하기나 소방호스를 연결하는 등의 동작 을 트레이닝 프로그램을 통해 실시하여 현장에서 장비를 신속하고 친숙하게 사용할 수 있도록 2차적인 효과도 가 져왔을 것으로 보인다. 소방공무원들은 화재현장이나 구 조상황에서 10 층 계단을 빠른 속도로 뛰어올라야 하는 심폐체력과 인명구조를 위해 사람을 엎고 탈출해야 하는 상당한 근력이 요구되는 상황이 빈번하게 발생한다. 서킷 트레이닝을 통해 모의 화재진압 수행력이 향상되었다는 것은 현장에서도 수월한 대처가 가능할 수 있다는 것을 의미한다. 연구에서 아쉬운 부분은 서킷트레이닝에 대한 상세한 운동프로그램이 제시되지 않아 향후 본 연구를 기 초로 서킷트레이닝을 구성할 때 구체적인 동작을 구현하 는데 다소 어려움이 있을 것으로 보인다.

연구G[20]은 56명의 소방공무원을 대상으로 운동프로 그램과 개별화된 프로그램을 제공하고 FMS 점수와 기능 체력이라고 할 수 있는 가동성, 안정성, 숙련된 움직임 등 의 변화를 분석하였다. 8 주간의 프로그램으로 통해 참가 자의 운동 능력, 안정성, 숙련된 움직임에서는 유의한 향 상을 가져왔으나 가동성에는 유의한 차이가 없는 것으로 나타났다. 소방공무원의 현장 특수성을 감안하여 기능체 력을 살펴본 것에 대해서는 의의가 있으나 특히 개인체 력에 따른 개별화된 프로그램 구성을 강조한 연구라 할 수 있다. 연구에서 2 명의 개별화된 프로그램을 예로 제시 
하였는데 프로그램 구성에 상당한 차이를 보여 결과도 프 로그램에 따라 매우 달라질 수 있을 것으로 예측된다. 8 주동안 운동프로그램을 실시하는 과정에서 self-monitoring으로 진행하였는데 운동전문가의 감독과 지도 하에 실시한 프로그램보다는 체계적인 부분이나 동기부여 면 에서 제한점으로 작용했을 가능성이 있어 보인다. 연구 $\mathrm{B}, \mathrm{D}, \mathrm{E}, \mathrm{F}[15,17,18,19]$ 와 같이 소방기관에서 동시에 진행했 다면 동기 부여도 되고 실천율도 높아져 더욱 긍정적인 결 과를 가져왔을 것이라 사료된다. 또한 프로그램의 구성이 근력 위주로 되어 있어 가동성 향상을 위해서는 근력과 더 불어 민첩성이나 평형성 등의 부분도 강조되어야 할 것으 로 보인다.

본 연구의 체계적인 고찰은 소방공무원을 위한 운동프 로그램을 구성할 때 객관적인 근거를 제공할 수 있으며 운 동프로그램을 계획하고 지도할 때 적절한 운동형태, 기 간, 부하 양 등 운동전문가의 의사결정에 중요한 역할을 할 수 있을 것으로 여겨진다. 현재까지 소방공무원을 대 상으로 운동프로그램에 대한 많은 연구들이 되어오고 있 지 않으나 소방공무원의 특수한 직무를 고려하여 기존 연 구를 바탕으로 후속 연구들이 더욱 활발하게 진행되어야 할 것으로 사료된다.

\section{결론}

체계적 선별과정을 통해 선정된 7편의 논문을 토대로 고찰을 한 결과, 소방공무원을 대상으로 한 운동과 재활 프로그램의 중요성을 확인할 수 있었고 체력증진과 부상 예방에 필요한 정보를 얻을 수 있었다. 소방공무원의 체력 을 증진시키고 부상을 최소화하기 위해서는 반드시 자격 을 갖춘 운동전문가의 지도 하에 실시되어야 하며, 심폐지 구력, 근체력 위주의 운동이 필수적으로 포함되어야 하겠 다. 부상 빈도가 높은 허리통증을 위해 코어운동과 등운동 의 효과적인 변화를 확인할 수 있었으며 근체력 가운데 코 어와 등근력 운동도 함께 구성되어야 할 것이다. 기존 연 구에서 제시한 운동프로그램을 근거로 과학적으로 한층 더 진보된 프로그램 개발이 매우 필요하며, 상당한 체력 이 요구되는 소방공무원의 직무를 고려할 때 적극적인 운 동참여와 실천율을 높일 수 있는 국가적인 지원이 가장 중 요한 요소라 할 수 있겠다.

\section{Acknowledgments}

본 연구는 순천향대학교 학술지원비(2018)와 한국소방 산업기술원의 현장중심형 소방활동지원 기술개발사업의 지원을 받아 연구되었음(MPSS-소방안전-2017-87).

\section{Conflicts of Interest}

The authors declare no conflict of interest.

\section{References}

1. Kim SG. A Study on the job stress of fire officers. [Master's dissertation]. [Seoul, Republic of Korea]: Dankook Universtsity Graduate School of Policy and Business Administration; 2002.

2. Petersen A, Payne W, Phillips M, Netto K, Nichols D, Aisbett B. Validity and relevance of the pack hike wildland firefighter work capacity test: a review. Ergon. 2010; 53(10):1276-85.

3. Oh CU. Fire officer physical enhancement program status quo and development plan. [Master's dissertation]. [Seoul, Republic of Korea]: Korea National Sport University Graduate School of Sports and Leisure Studies; 2013.

4. Kim JM. A Study on the body state and improving the physical fitness of fire officials. [Master's dissertation]. [Seoul, Republic of Korea]: Korea National Sport University Graduate School of Sports and Leisure Studies; 2005.

5. Hong SK. The setting of physical fitness test items for the job performance of firefighter's. [PhD dissertation]. [Incheon, Republic of Korea]: Incheon National University Graduate School; 2010

6. Seong BJ, Ko BG, Kim JH, et al. Development of physical fitness program for firefighters. NSPC. Report on the assignment task. 2008.

7. Kim NI, Jang JH, Seong KH, et al. Aerobic exercise capacity and isokinetic muscle strength on duty form in firefighters. JKSAE. 2002; 6(1):17-32.

8. Ko BG. The relationship between firefighting performance 
and physical fitness. KJSS. 2006; 17(1):66-74.

9. Myhre LG, Tucker DM, Bauer DH, et al. Relationship between selected measures of physical fitness and performance of a simulated firefighting emergency task. 1997, http://www.dtic.mil/dtic/tr/fulltext/u2/ a319915.pdf

10. Michaelides MA, Parpa KM, Thompson J, Brown B. Predicting performance on a firefighters ability test from fitness parameters. RQES. 2008; 79(4):468-75.

11. Sheaff AK, Bennett A, Hanson ED, et al. Physiological determinants of the candidate physical ability test in firefighters. J Strength Cond Res. 2010; 24(11):3112-22.

12. Jo GH, Lee BE, Lee SH. Relationship between firefighting suppression tasks and physical fitness. Disaster Prev Res. 2004; 6(3):139-49.

13. Cochrane Handbook for Systematic Reviews of Interventions. 2009, http://www.cochrane-handbook.org

14. Roberts MA, O'dea J, Boyce A, Mannix ET. Fitness levels of firefighter recruits before and after a supervised exercise training program. J Strength Cond Res. 2002;16(2):271-7.

15. Carey MG, Al-Zaiti SS, Liao LM, Martin HN, Butler RA. A low-glycemic nutritional fitness program to reverse metabolic syndrome in professional firefighters: results of a pilot study. J Cardiovasc Nurs. 2011; 26(4):298-304.

16. Gwon HJ. The effects of the lumbago program on the muscular pain and the function of firefighters with back pain. [Master's dissertation]. [Kangwon, Republic of Korea]: Kangwon National University Graduate School of Industry and Science; 2013.

17. Mayer JM, Quillen WS, Verna JL, Chen R, Lunseth P, Dagenais S. Impact of a supervised worksite exercise program on back and core muscular endurance in firefighters. Am J Health Promot. 2015; 29(3):165-72.

18. Mayer JM, Nuzzo JL. Worksite back and core exercise in firefighters: effect on development of lumbar multifidus muscle size. Work. 2015; 50(4):621-7.

19. Pawlak R, Clasey JL, Palmer T, Symons TB, Abel MG. The effect of a novel tactical training program on physical fitness and occupational performance in firefighters. J
Strength Cond Res. 2015; 29(3):578-88.

20. Stanek JM, Dodd DJ, Kelly AR, Wolfe AM, Swenson RA. Active duty firefighters can improve Functional Movement Screen (FMS) scores following an 8-week individualized client workout program. Work. 2017; 56(2):213-20.

21. Gledhll N, Jamnik VK. Characterization of the physical demands of firefighting. Can J Sports Sci. 1992; 17:207-13.

22. Gami AS, Witt BJ, Howard DE, et al. Metabolic syndrome and risk of incident cardiovascular events and death: a systematic review and meta-analysis of longitudinal studies. J Am Coll Cardiol. 2007; 49(4):403-14.

23. National Cholesterol Education Program (NCEP) Expert Panel on Detection, Evaluation, and Treatment of High Blood Cholesterol in Adults (Adult Treatment Panel III). Third report of the national cholesterol education program (NCEP) Expert panel on detection, evaluation, and treatment of high blood cholesterol in adults (Adult Treatment Panel III) final report. Circulation. 2002; 106(25):3143-3421.

24. Pitsavos C, Panagiotakos D, Weinem M, Stefanadis C. Diet, exercise and the metabolic syndrome. Rev Diabet Stud. 2006; 3(3):118-26.

25. Butler RJ, Contreras M, Burton LC, Plisky PJ, Goode A, Kiesel K. Modifiable risk factors predict injuries in firefighters during training academies. Work. 2013; 46(1):11-7.

26. Nuwayhid I, Stewart W, Johnson J. Work activities and the onset of first-time low back pain among New York City fire fighters. Am J Epidemiol. 1993; 137(5):53948.

27. Gentzler M, Stader S. Posture stress on firefighters and emergency medical technicians associated with repetitive reaching, bending, lifting, and pulling tasks. Work. 2010; 37(3):227-39.

28. Beneck GJ, Kulig K. Multifidus atrophy is localized and bilateral in active persons with chronic unilateral low back pain. Arch Phys Med Rehabil. 2012; 93(2):300-6.

29. Hides JA, Gilmore C, Stanton WR, Bohlscheid E. Multifidus size and symmetry among chronic LBP and 
healthy asymptomatic subjects. Man Ther. 2008; 13(1):43-9.

30. Shabani R, Nazari M, Dalili S, Rad AH. Effect of circuit resistance training on glycemic control of females with diabetes type II. Int J Prev Med. 2015: 10;1-11.
31. Arazi H, Ghiasi A, Afkhami M. Effects of different rest intervals between circuit resistance exercises on post-exercise blood pressure responses in normotensive young males. Asian J Sports Med. 2013 ;4(1):63-9. 